\title{
EVALUATION OF SERUM-PLEURAL FLUID ALBUMIN GRADIENT FOR DIFFERENTIATION OF TRANSUDATE AND EXUDATE
}

\author{
Vasudevan Palanikumaran', Sappani Kasipandian², Manickam Natarajan ${ }^{3}$
}

1 Junior Resident, Department of Medicine, Madurai Medical College and Government Rajaji Hospital, Madurai, Tamilnadu. ${ }^{2}$ Assistant Professor, Department of Medicine, Madurai Medical College and Government Rajaji Hospital, Madurai, Tamilnadu. 3Professor, Department of Medicine, Madurai Medical College and Government Rajaji Hospital, Madurai, Tamilnadu.

\section{ABSTRACT}

\section{BACKGROUND}

The correct diagnostic approach of any Pleural Effusion (PE) is differentiation between Transudates and Exudates. The Light's criteria is used to differentiate between the two, but up to $25 \%$ of Transudates are misclassified as Exudates. To overcome this, the gradient between Serum (Sr.) - Pleural Fluid (PF) Albumin should be measured. A gradient of $>1.2$ gm/dL has good sensitivity and specificity for confirming transudates.

The aim of this study was to estimate the Sr. - PF Albumin gradient and comparing it with Light's criteria for its efficacy in the identification of Transudates misclassified by Light's criteria as Exudates.

\section{MATERIALS AND METHODS}

This is a descriptive study. It was conducted on 50 patients who had only transudative PE with the clinical background of Congestive Cardiac Failure (CCF), Chronic Kidney Disease (CKD) and Hepatic hydrothorax admitted in Medical wards of Govt. Rajaji Hospital, Madurai.

\section{RESULTS}

According to PF - Sr. Protein ratio in the Light's criteria, 78\% of the cases were detected as Transudative PE. According to Sr. - PF Albumin gradient, $96 \%$ of the cases were detected as Transudative PE. According to Sr. - PF Protein gradient, $88 \%$ of the cases were detected as Transudative PE.

\section{CONCLUSION}

By using Sr. - PF Albumin gradient, our study correctly classified $96 \%$ as Transudative PE and by applying Light's criteria only $78 \%$ were classified as Transudative PE. So, Light's criteria wrongly classified 22\% of Transudative PE as Exudative PE, whereas Sr. - PF Albumin gradient classified only 4\% of Transudative PE as Exudative PE. Sr. - PF Protein gradient correctly classified $88 \%$ of Transudative PE and wrongly classified $12 \%$ of them. From our study, it is conclusive that Sr. - PF Albumin gradient is an effective means of differentiating Exudative and Transudative PE.

\section{KEYWORDS}

Pleural Effusion, Congestive Cardiac Failure, Chronic Kidney Disease, Hepatic Hydrothorax, Transudate, Exudate.

HOW TO CITE THIS ARTICLE: Palanikumaran V, Kasipandian S, Natarajan M. Evaluation of serum-pleural fluid albumin gradient for differentiation of transudate and exudate. J. Evolution Med. Dent. Sci. 2017;6(48):3711-3716, DOI: 10.14260/Jemds/2017/801

\section{BACKGROUND}

The Light's criteria ${ }^{1}$ is used to differentiate the Transudative PE from Exudative PE with one or more of the following: a) $\mathrm{PF}$ Protein/Sr. Protein ratio $>0.5 ;$ b) $\mathrm{PF}$ Lactic Dehydrogenase (LDH)/Sr. LDH ratio > 0.6; c) PF LDH is more than $2 / 3^{\text {rd }}$ of the upper limit of Sr. LDH. If any one of these critical values is exceeded, the effusion is an exudate.

By applying Light's criteria up to $25 \%$ of Transudative PE are misclassified as Exudative PE. Serum-PF Albumin should be measured and if it is $>1.2 \mathrm{gm} / \mathrm{dL}$ it has good sensitivity and specificity for confirming as Transudative PE.

Financial or Other, Competing Interest: None.

Submission 22-05-2017, Peer Review 03-06-2017,

Acceptance 09-06-2017, Published 15-06-2017.

Corresponding Author:

Dr. Sappani Kasipandian,

"Devi Illam,"

No. 3/423/5,

Meenakshi Amman Street,

Opp. to Pandi Kovil,

Pandian Nagar, Madurai - 625020.

E-mail: sankarkasipandian@yahoo.com

DOI: $10.14260 /$ jemds $/ 2017 / 801$

(c) (i) $\ominus$
This present study is to evaluate the Sr. - PF Albumin gradient in differentiating Transudative PE and Exudative PE. To compare the validation in differentiating a Transudative PE from Exudative PE among 3 parameters such as- 1) Sr.-PF protein ratio, 2) Sr.-PF Protein gradient and 3) Sr.-PF Albumin gradient.

An exudative PE results from disease of the pleural surface itself, while a transudative PE results from alterations in the systemic factors that influence the movement of fluid in and out of the pleural space. ${ }^{2}$ The criteria established by Light et $\mathrm{al}^{1}$ for segregating transudates from exudates have been widely accepted and rely on measurement of protein and Lactate Dehydrogenase (LDH) in serum and PF. In an effort to improve the sensitivity and specificity of the classic criteria of Light et al, Romero et $\mathrm{al}^{3}$ have recently proposed their modification by the adaptation of new cut-off points for the biochemical analytes, i.e. PF. Protein/Sr. Protein ratio $>0.6$, PF LDH/Sr. LDH ratio > 0.9 and PF LDH level > $280 \mathrm{IU}$.

The hydrostatic pressure in the parietal pleura is approximately $(\approx) 30 \mathrm{~cm}$ of water $\left(\mathrm{H}_{2} \mathrm{O}\right)$ and the pleural pressure is $\approx-5 \mathrm{~cm}$ of $\mathrm{H}_{2} \mathrm{O}$. The net hydrostatic pressure is 30 $-(-5)=35 \mathrm{~cm}$ of $\mathrm{H}_{2} \mathrm{O}$ and this favours the movement of fluid from the capillaries in the parietal pleura to the pleural space. 
The normal oncotic pressure of the plasma is $\approx 34 \mathrm{~cm}$ of $\mathrm{H}_{2} \mathrm{O}$, which is opposing the hydrostatic pressure gradient of the parietal pleura. Normally, the small amount of PF contains a small amount of protein with an oncotic pressure of $(\approx) 5 \mathrm{~cm}$ of $\mathrm{H}_{2} \mathrm{O}$, yielding a net oncotic pressure gradient of $34-5=29$ $\mathrm{cm}$ of $\mathrm{H}_{2} \mathrm{O}$, the net pressure gradient i.e. (net hydrostatic pressure- net oncotic pressure) $35-29=6 \mathrm{~cm}$ of $\mathrm{H}_{2} \mathrm{O}$, favouring the movement of fluid from the capillaries in the parietal pleura to the pleural space.

The net gradient for fluid movement across the visceral pleura is probably zero. ${ }^{4}$ The pressure in the visceral pleural capillaries is $\approx 6 \mathrm{~cm}$ of $\mathrm{H}_{2} \mathrm{O}$ less than that in the parietal pleural capillaries $6 \mathrm{~cm}$ of $\mathrm{H}_{2} \mathrm{O}$. So the visceral pleural capillaries drain into the pulmonary veins and it is the only pressure that differs from those affecting fluid movement across the parietal pleura. The filtration coefficient for the visceral pleura is less than the parietal pleura, because the capillaries in the visceral pleura are much farther from the pleural space than those in the parietal pleura.

The origin of the fluid does not appear to be in the interstitial spaces of the lung, because the protein level in the interstitial spaces is $\approx 4.5 \mathrm{~g} / \mathrm{dL}$, whereas the protein level in normal $\mathrm{PF}$ is $\approx 1$ to $1.5 \mathrm{~g} / \mathrm{dL}$, higher vascular pressures should produce PF with lower protein levels. ${ }^{4}$

The pleural space is in communication with the lymphatic vessels in the parietal pleura by means of stomas in the parietal pleura, which is absent in the visceral pleura. Transcytosis also contributes to the removal of PF protein from the pleural space. Only $29 \%$ of the overall removal of albumin occurred through the stoma with small hydrothoraces, while $64 \%$ of the removal of albumin occurred through the stoma with large hydrothoraces.

The proteins, cells and all other particulate matters are removed from the pleural space by these lymphatics in the parietal pleura. Increased levels of Nitric Oxide in the pleura will cause these stoma to increase in size. Normal lymphatic drainage in an adult from each pleural space is $20 \mathrm{~mL} / \mathrm{hr}$ or $500 \mathrm{~mL} /$ day. The capacity for lymphatic clearance is 28 times as high as the normal rate of PF formation.

The primary route for the exit of fluid from the pleural space was through the capillaries in the visceral pleura and almost all the PF is removed through the lymphatics in the parietal pleura. Several hundred millilitres (mLs) of water probably traverse the pleural membranes each day, but the net movement is of only a few mLs, because the osmolarity is nearly identical on each side of the membrane.

The most common cause of increased PF formation is due to increased interstitial fluid in the lungs. Whenever the amount of oedema in the lung exceeds 5 gm/gram of dry lung weight, $\mathrm{PF}$ accumulates irrespective of whether the oedema is due to high-protein or low-protein fluid and appears to be the predominant mechanism for the accumulation of PE in CCF, Parapneumonic effusions, ARDS and in post lung transplantation status.

With an increase in the gradient between the intravascular pressure and the pleural pressure, there will be an increase in the rate of PF formation through Starling's equation. Increased intravascular pressure can occur with right ventricular failure, left ventricular failure, pericardial effusions or SVC syndrome. The most common situation producing a decrease in the pleural pressure is bronchial obstruction leading to atelectasis of the lower lobe or entire lung, when the visceral pleura becomes coated with a collagenous peel and the lung becomes trapped. Decreased pleural pressures also contribute to PF accumulation due to the elastic recoil of the diseased lung is increased.

The increased levels of Vascular Endothelial Growth Factor (VEGF) increases the permeability of the capillaries and leads to accumulation of PF. VEGF levels are higher in Exudative PE than in Transudative PE. If the pleural surfaces become inflamed the permeability of the capillaries may be increased, which leads to increased PF protein levels occur in pulmonary oedema, haemothorax. This rate of fluid formation is equal to the capacity of the lymphatics to remove PF.

The free fluid in the peritoneal cavity will lead to PF accumulation through the diaphragm and Chyle will accumulate in the pleural space if there is a disruption in the thoracic duct, and blood will accumulate in the pleural space if there is a disruption of a blood vessel in the thorax.

The most common cause of a decrease in PF absorption is obstruction of the lymphatics draining the parietal pleura. Normally, the lymphatic flow from the pleural space is approximately $0.01 \mathrm{~mL} / \mathrm{kg} /$ hour or $15 \mathrm{~mL} /$ day, which is equal to the amount of PF formed. The capacity of the lymphatics is approximately $0.20 \mathrm{~mL} / \mathrm{kg} / \mathrm{hour}$ or 300 $\mathrm{mL} /$ day. Lymphatic blockade is an important factor for the development of a malignant pleural effusion.

The causes for Transudative PE are CCF, Cirrhosis, Nephrotic syndrome and Glomerulonephritis, SVC Syndrome, Peritoneal dialysis, Myxoedema and Hypoalbuminaemia.

The causes for Exudative PE are Tuberculous, Bacterial, Fungal, Parasitic and Viral infections, Neoplastic and Metastatic diseases, Mesothelioma, Lymphomas, Pulmonary embolisation, Haemothorax and Chylothorax, Pancreatic diseases, Endoscopic variceal sclerosis, Subphrenic, Intrahepatic and Intrasplenic abscess. Post CABG surgery, Post cardiac injury (Dressler's) syndrome, Pericardial diseases, Pulmonary vein stenosis, Post catheter ablation of atrial fibrillation, Meigs' syndrome, Rheumatoid pleuritis, Systemic lupus erythematosus and Drug-induced pleural disease, e.g. Amiodarone, Methotrexate, Procarbazine, Methysergide and Dantrolene.

When symptoms are related to the effusion they arise from inflammation of the pleura, compromise the pulmonary mechanics, interfere with gas exchange and decrease cardiac output. PE associated with pleuritic chest pain indicates inflammation of the pleura, specifically the parietal pleura, whereas the visceral pleura does not have pain fibres. Some patients with PE experience a dull aching chest pain rather than pleuritic chest pain.

The pleural effusion is probably due to CCF if the patient has cardiomegaly, signs of joint disease or subcutaneous nodules suggest that the PF is due to rheumatoid disease or lupus erythematosus. An enlarged, non-tender nodular liver or the presence of hypertrophic osteoarthropathy suggests metastatic disease, as do breast masses or the absence of a breast. Abdominal tenderness suggests a subdiaphragmatic process, whereas tense ascites suggests cirrhosis and a hepatothorax. Lymphadenopathy suggests lymphoma, metastatic disease or sarcoidosis.

Most transudative PE are clear, straw-coloured, nonviscid and odourless. The PF appears as pinkish tinge if red blood cell (RBC) count is of more than $10,000 / \mathrm{mm}^{3}$. Approximately, 15\% have RBC counts above this level. ${ }^{5}$ 


\section{Aims and Objectives}

To estimate the Sr. - PF Albumin gradient and comparing it with Light's criteria for its efficacy in the identification of transudates misclassified by Light's criteria as exudates.

\section{MATERIALS AND METHODS}

This descriptive study was conducted on 50 patients in number who had only Transudative pleural effusion with the clinical background of CCF, CKD and Hepatic hydrothorax admitted in Medical wards of Govt. Rajaji Hospital affiliated to Madurai Medical College, Madurai. Prior written consent was obtained from all the patients included in the study in their own mother tongue. For convenience, sample size of 50 was taken; patients with Transudative $\mathrm{PF}$ with the clinical background of CCF, CKD and Hepatic hydrothorax of all age groups and both sexes. Patients with clinical features suggestive of Exudative PE such as Tuberculous PF, Malignant $\mathrm{PF}$ and Parapneumonic effusions are to be excluded from the study. Sr. - PF Albumin gradient is a better parameter for identifying Transudative PE compared with Light's criteria. A detailed clinical history, detailed clinical examinations, laboratory estimations of PF Protein, Albumin and Sr. Albumin and Sr. Protein were taken. Patients with CCF, CKD and Hepatic Hydrothorax with Clinical or Radiological evidence of PF are included in the study. Patients whose lab reports favours exudates according to Light's criteria are compared with Sr. - PF Albumin gradient to analyse the validity of Light's criteria in diagnosing transudates; 7 months duration from April 2013 to October 2013. After obtaining the results, the data was compiled in a Microsoft Excel sheet. Statistical analysis was done using IBM Statistical Package for Social Sciences Software version 2.0. Standard deviation and ' $p$ ' values, Kappa values were calculated. Chisquare test, Student's ' $\mathrm{t}$ ' test, One Way ANOVA test and $\mathrm{p}$ value $<0.05$ was taken as significant. All statistical tests were interpreted at $5 \%$ level of significance.

\section{RESULTS}

This study was conducted on 50 patients who had only Transudative PE with the clinical background of CCF, CKD and Hepatic hydrothorax.

CCF was diagnosed in 11 females and 8 males if the patient had oedematous legs, radiological evidence of cardiomegaly, congested lungs and responded to treatment for CCF.

CKD was diagnosed in 6 females and 12 males with raised Sr. urea and Sr. creatinine levels along with signs and symptoms of volume overload.

Hepatic hydrothorax was diagnosed in 4 females and 9 males if the patient had features of liver cell failure, ascites, splenomegaly and evidence of volume overload status.

\begin{tabular}{|c|c|c|}
\hline Age Group & Frequency & Percent \\
\hline $41-50$ years & 8 & 16 \\
\hline $51-60$ years & 24 & 48 \\
\hline $61-70$ years & 17 & 34 \\
\hline$>70$ years & 1 & 2 \\
\hline Total & $\mathbf{5 0}$ & $\mathbf{1 0 0 . 0}$ \\
\hline
\end{tabular}

Table 1. Age Distribution of the Study Population ( $n=50)$

In our study $82 \%$ (41) patients were in the age group of 51 - 70 years, while $16 \%$ (8) patients were in the age group of
41 - 50 years and patient's mean age was $57.5 \pm$ S.D. 6.82 , minimum 43 years, maximum 75 years of age.

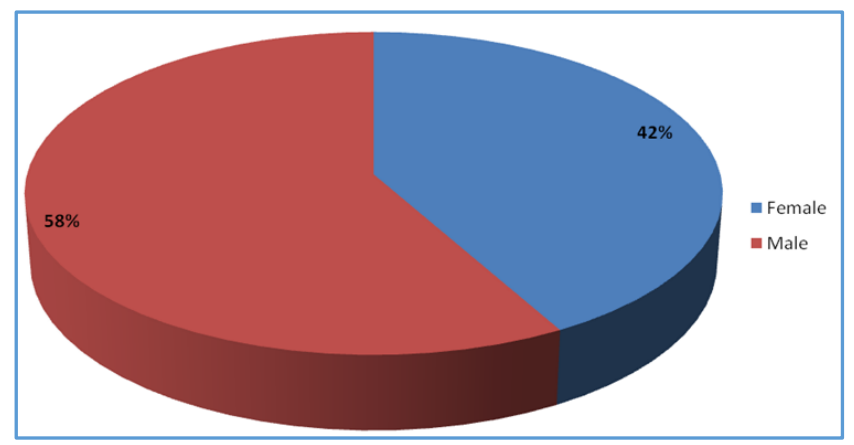

Figure 1. Gender Distribution of the Study Population ( $n=50)$

Majority of the study subjects were males $58 \%$ (29) patients, while remaining $42 \%$ (21) patients were females.

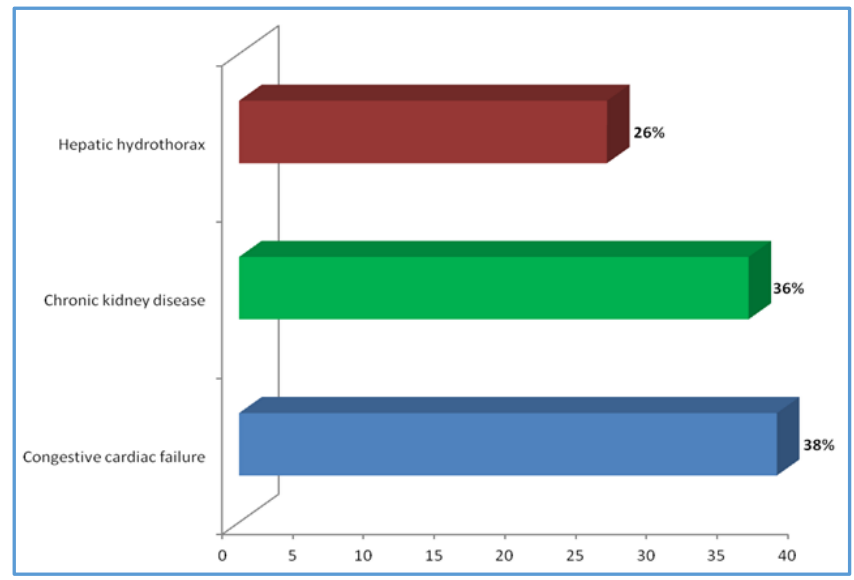

Figure 2. Distribution of the Study Population according to Clinical Diagnosis $(n=50)$

About 38\% (19) patients had CCF, 36\% (18) had CKD and 26\% (13) patients had Hepatic hydrothorax.

\begin{tabular}{|c|c|c|c|c|}
\hline $\begin{array}{c}\text { Descriptive } \\
\text { Statistic }\end{array}$ & $\begin{array}{c}\text { Sr. } \\
\text { Protein } \\
\text { (gm/dL) }\end{array}$ & $\begin{array}{c}\text { Sr. } \\
\text { Albumin } \\
\text { (gm/dL) }\end{array}$ & $\begin{array}{c}\text { P.F. } \\
\text { Protein } \\
\text { (gm/dL) }\end{array}$ & $\begin{array}{c}\text { P.F. Albumin } \\
\text { (gm/dL) }\end{array}$ \\
\hline Mean & 6.26 & 3.15 & 2.64 & 1.32 \\
\hline $\begin{array}{c}\text { Standard } \\
\text { Deviation }\end{array}$ & 0.2897 & 0.4427 & 0.4385 & 0.2310 \\
\hline Minimum & 5.6 & 2.2 & 1.8 & .9 \\
\hline Maximum & 6.8 & 3.8 & 3.3 & 1.8 \\
\hline \multicolumn{7}{|c|}{$\begin{array}{c}\text { Table 2. Descriptive Statistics of Sr. and PF Protein and } \\
\text { Albumin Levels of the Study Population (n= 50) }\end{array}$} \\
\hline
\end{tabular}

The mean level of protein in Sr. and PF was $6.26 \mathrm{gm} / \mathrm{dL}$ and $2.64 \mathrm{gm} / \mathrm{dL}$, respectively. The mean level of Albumin in Sr. and PF was $3.15 \mathrm{gm} / \mathrm{dL}$ and $1.32 \mathrm{gm} / \mathrm{dL}$, respectively. 


\begin{tabular}{|c|c|c|c|}
\hline $\begin{array}{c}\text { Descriptive } \\
\text { Statistic }\end{array}$ & $\begin{array}{c}\text { (P.F./Sr.) } \\
\text { Protein Ratio }\end{array}$ & $\begin{array}{l}\text { (P.F./Sr.) } \\
\text { Protein } \\
\text { Gradient }\end{array}$ & $\begin{array}{l}\text { (P.F./Sr.) } \\
\text { Albumin } \\
\text { Gradient }\end{array}$ \\
\hline Mean & 0.4218 & 3.622 & 1.834 \\
\hline Std. Deviation & 0.06467 & 0.4117 & 0.3414 \\
\hline Minimum & 0.31 & 3.1 & 1.2 \\
\hline Maximum & 0.52 & 4.5 & 2.7 \\
\hline
\end{tabular}

The mean level of PF Protein to Sr. Protein ratio was 0.42 . The mean level of Sr. - PF Protein gradient was 3.62, while Sr. - PF Albumin gradient was 1.8.

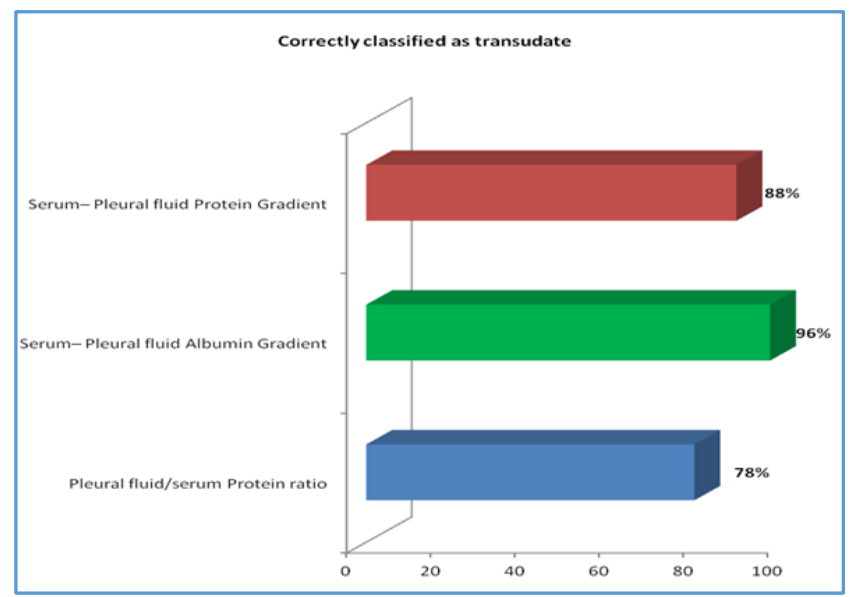

Figure 3. Distribution of Correctly Classified Transudative PF $(n=50)$

By applying Light's criteria for PF Protein/Sr. Protein ratio, 78\% (39) of the cases were detected as Transudative PE and according to Sr. - PF Albumin gradient, 96\% (48) of the cases were detected as Transudative PE. According to Sr. PF Protein gradient, 88\% (44) of the cases were detected as Transudative PE.

The misclassification of subjects as Exudative PE by each criterion does not vary with the type of clinical diagnosis.

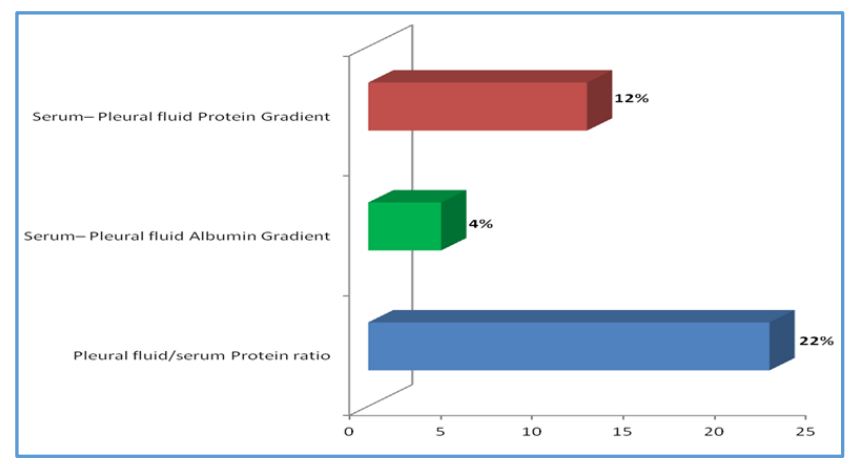

Figure 4. Distribution of Transudates, Wrongly Classified as Exudates

\begin{tabular}{|c|c|c|c|c|c|}
\hline \multirow{2}{*}{\multicolumn{2}{|c|}{ Variables }} & C.K.D. & C.C.F. & $\begin{array}{c}\text { Hepatic } \\
\text { Hydro- } \\
\text { Thorax }\end{array}$ & \multirow{2}{*}{$\begin{array}{l}\text { ANOVA } \\
\text { Test } \\
p \text { value }\end{array}$} \\
\hline & & Mean & Mean & Mean & \\
\hline \multicolumn{2}{|c|}{ Age } & 59 & 58 & 54 & 0.165 \\
\hline \multirow{2}{*}{ Sex* } & Female & 6 & 11 & 4 & \multirow{2}{*}{$0.20^{* *}$} \\
\hline & Male & 12 & 8 & 9 & \\
\hline \multicolumn{2}{|c|}{$\begin{array}{l}\text { Sr. Protein } \\
\text { (gm/dL) }\end{array}$} & 6.4 & 6.3 & 6.0 & $<0.001$ \\
\hline \multicolumn{2}{|c|}{$\begin{array}{l}\text { Sr. Albumin } \\
\text { (gm/dL) }\end{array}$} & 3.4 & 3.4 & 2.5 & $<0.001$ \\
\hline \multicolumn{2}{|c|}{$\begin{array}{l}\text { P.F. Protein } \\
\text { (gm/dL) }\end{array}$} & 2.6 & 2.7 & 2.6 & 0.80 \\
\hline \multicolumn{2}{|c|}{$\begin{array}{l}\text { P.F. Albumin } \\
\text { (gm/dL) }\end{array}$} & 1.5 & 1.3 & 1.1 & $<0.001$ \\
\hline
\end{tabular}

Table 4. Distribution of Study Population according to Clinical Diagnosis and Baseline Data with Bio-Chemical Parameters $(n=50)$

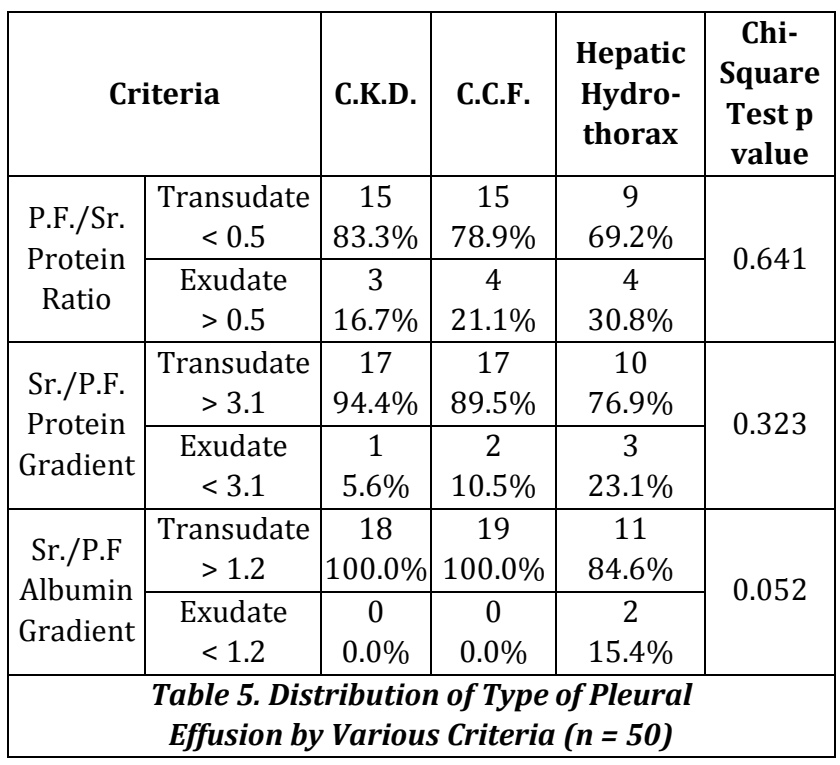

\section{Comments}

The misclassification of subjects as exudative PF by each criterion does not vary with the type of clinical diagnosis, i.e. the percentage of misclassification transudate as exudates is similar in all 3 types of clinical diagnosis.

\begin{tabular}{|c|c|c|c|c|}
\hline \multicolumn{2}{|c|}{} & \multicolumn{2}{c|}{$\begin{array}{c}\text { Sr. - P.F. } \\
\text { Protein Gradient }\end{array}$} & \multirow{2}{*}{ Total } \\
\cline { 3 - 5 } & $\begin{array}{c}\text { Transudate } \\
>\mathbf{3 . 1}\end{array}$ & $\begin{array}{c}\text { Exudate } \\
<3.1\end{array}$ & \\
\hline $\begin{array}{c}\text { P.F./Sr. } \\
\text { Protein } \\
\text { Ratio } \\
\text { (Light's) }\end{array}$ & $\begin{array}{c}\text { Transudate } \\
<0.5\end{array}$ & $39(88.6 \%)$ & $\begin{array}{c}0 \\
(0 \%)\end{array}$ & $\begin{array}{c}39 \\
(78 \%)\end{array}$ \\
\cline { 2 - 5 } & $>0.5$ & $5(11.4 \%)$ & $\begin{array}{c}6 \\
(100 \%)\end{array}$ & $\begin{array}{c}11 \\
(22 \%)\end{array}$ \\
\hline \multicolumn{2}{|c|}{ Total } & $44(100 \%)$ & $\begin{array}{c}6 \\
(100 \%)\end{array}$ & $\begin{array}{c}50 \\
(100 \%)\end{array}$ \\
\hline \multicolumn{2}{|c|}{$\begin{array}{c}\text { Table 6. Agreement between P.F./Sr. Protein } \\
\text { Ratio and Sr./P.F. Protein Gradient (n= 50) }\end{array}$} \\
\hline
\end{tabular}

Kappa value: 0.65 (p value: $<0.001$ ) 


\section{Comments}

There was statistically significant agreement between PE/Sr. protein ratio and Sr. and PF Protein gradient and it was 65\%, i.e. about $65 \%$ of cases are either correctly classified as transudate or incorrectly classified as exudate by both these criteria.

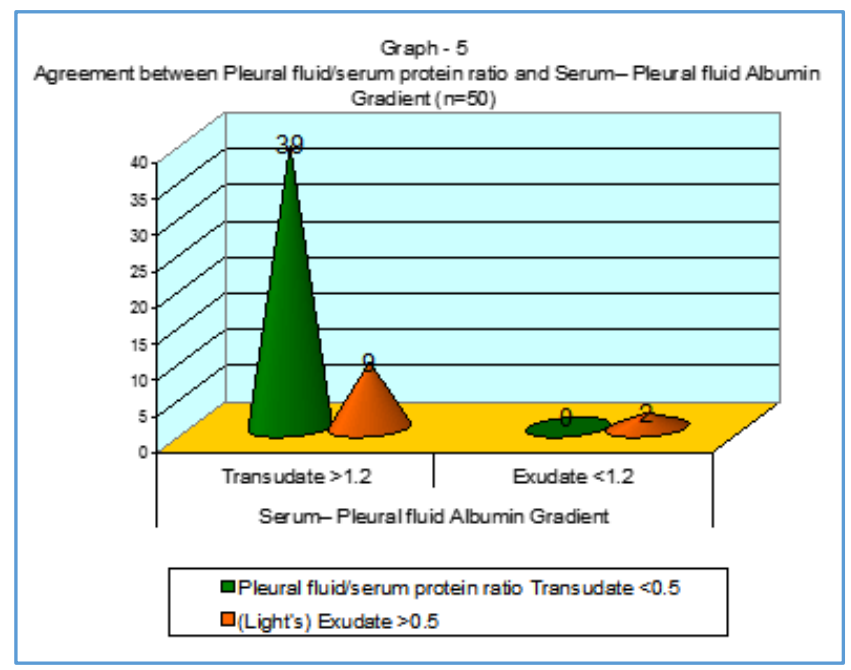

Kappa value: 0.25 (p value: 0.007 )

\section{Comments}

There was statistically significant agreement between P.E/Sr. protein ratio and Sr. and PF Albumin gradient and it was $25 \%$.

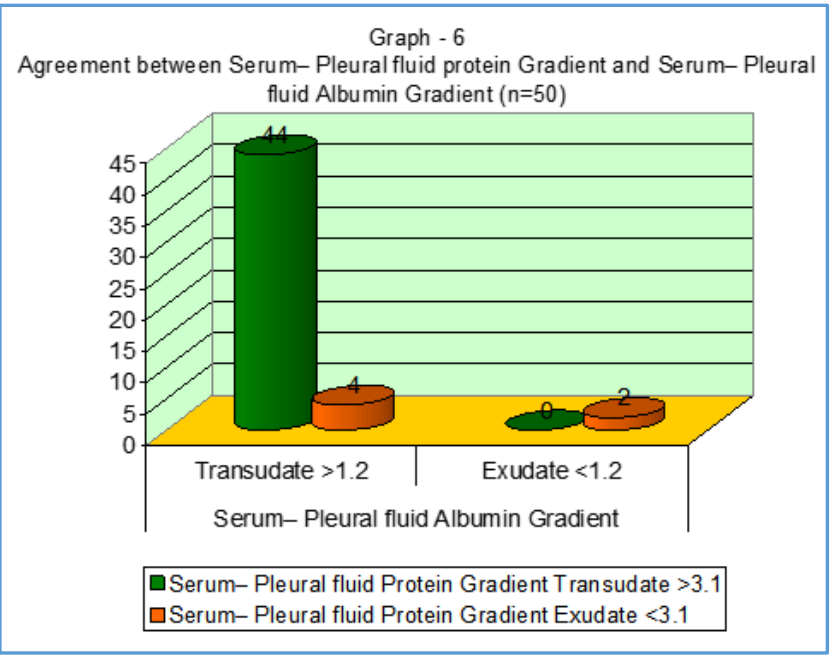

Kappa value: 0.46 ( $\mathrm{p}$ value: $<0.001)$

\section{Comments}

There was statistically significant agreement between PF/Sr. protein ratio and Sr. and PF Albumin gradient and it was $46 \%$.

\section{DISCUSSION}

In our studies by applying the Light's criteria, about 22\% (11) of Transudative PE was wrongly diagnosed as Exudative PE, whereas by applying Sr. - PF Protein gradient the misclassification was only $12 \%(6)$ and by applying Sr. - PF Albumin gradient the misclassification was only in $4 \%$ (2) cases.
Arijith Kumardas et $\mathrm{al}^{6}$ evaluated 40 patients of both Transudative and Exudative PE with various parameters and compared to differentiating Transudative PE from Exudative PE. By applying PF to Sr. Protein ratio, $20 \%$ of Transudative PE are misclassified as Exudative PE, but Sr. - PF Albumin gradient misclassified only $5 \%$. They have concluded that $\mathrm{Sr}$. PF Albumin gradient is a very useful parameter between Exudative PE and Transudative PE, especially in cases misclassified by Light's criteria.

Another study by KB Gupta et al, 5 they evaluated a total of 60 patients of PE of varied causes. They measured Sr. - PF Albumin gradient and the results were compared with Light's criteria to distinguish between Transudative PE and Exudative PE. The cut-off value of $1.2 \mathrm{gms} / \mathrm{dL}$ was able to differentiate between Transudative PE and Exudative PE with sensitivity of $97.9 \%$ and $100 \%$, respectively. They concluded this parameter was found to be better than Light's criteria, especially in respect to misclassified PE.

The study conducted by MC Dhar, S Chaudhuri et al, ${ }^{7}$ on 50 patients with PE were evaluated. Sr. - PF Albumin gradient and Light's criteria were compared. Light's criteria misdiagnosed 2 of 5 Transudative, but by using Sr. - PF Albumin gradient all patients were correctly diagnosed. They concluded that Light's criteria was accurate for identifying Exudative PE, but not so much in case of Transudative PE. The Sr. - PF Albumin gradient is accurate equally for Transudative PE and Exudative PE.

A recent study by Silvia Bielsa et al ${ }^{8}$ evaluated 364 Cardiac effusions and 102 Hepatic hydrothorax Sr. - PF Albumin ratio and Sr. - PF Albumin gradient were evaluated. Light's criteria misclassified Cardiac effusion and Hepatic hydrothorax as Exudate. Albumin gradient $>1.2 \mathrm{gms} / \mathrm{dL}$ correctly identified false Exudative PE and they concluded Albumin gradient is a better indicator in Cardiac effusion.

\section{CONCLUSION}

By using Sr. - PF Albumin gradient, our study correctly classified $96 \%$ as Transudative PE and by applying Light's criteria in these subjects only $78 \%$ of them were classified as Transudative PE. So Light's criteria wrongly classified 22\% (11) of Transudative PE as Exudative PE, whereas Sr. - PF Albumin gradient classified only 4\% (2) of Transudative PE as Exudative PE. Sr. - PF Protein gradient correctly classified $88 \%$ as Transudative PE and wrongly classified $12 \%$ of Transudative PE as Exudative PE. The classic criteria of differentiating Exudative PE from Transudative PE by Light's criteria misclassified significant numbers of Transudative PE as Exudative PE.

From our study, it is conclusive that Sr. - PF Albumin gradient is an effective measure of differentiating exudative PE and Transudative PE. This Sr. - PF Protein gradient and Sr. - PF Albumin gradient are especially a good marker for differentiating Transudative PE from Exudative PE in patients with CCF, CKD and Hepatic hydrothorax.

\section{REFERENCES}

[1] Light RW, MacGregor MI, Luchsinger PC, et al. Pleural effusion: the diagnostic separation of transudates and exudates. Ann Intern Med 1972;77(4):507-13.

[2] Light RW. Pleural disease. $3^{\text {rd }}$ edn. Baltimore: Williams \& Wilkins 1995:7-17. 
[3] Romero S, Candela A. Martin C, et al. Evaluation of different criteria for the separation of pleural transudates from exudates. Chest 1993;104(2):339404.

[4] Miserocchi G, Agostoni E. Contents of pleural space. J Appl Physiol 1971;30(2):208-13.

[5] Gupta KB, Aggarwal SK, Kumar S, et al. Evaluation of plasma pleural effusion albumin gradient for differentiating between pleural transudate and exudate. Indian Journal of Tuberculosis 2003;50:23-9.
[6] Das AK, Baruah K. Study on significance of serum effusion albumin gradient in the differential diagnosis of pleural effusion. JK Science 2009;11(3):123-6.

[7] Dhar MC, Chaudhuri S, Basu K, et al. Significance of serum-effusion albumin gradient in the differential diagnosis of pleural effusion. Indian Journal of tuberculosis 2000;47(4):229-31.

[8] Bielsa S, Porcel JM, Castellote J, et al. Solving the Light's criteria misclassification rate of cardiac and hepatic transudates. Respirology 2012;17(4):721-6. 